Título artículo / Títol article: Application of Fast Gas ChromatographyMass Spectrometry in Combination with the QuEChERS Method for the Determination of Pesticide Residues in Fruits and Vegetables

Autores / Autors

Laura Cherta, Joaquim Beltrán, Francisco López, Félix Hernández

Revista:

Food Analytical Methods

Versión / Versió:

Versió post-print de l'autor

Cita bibliográfica / Cita bibliogràfica (ISO 690):

CHERTA, Laura, et al. Application of fast gas chromatography-mass spectrometry in combination with the QuEChERS method for the determination of pesticide residues in fruits and vegetables. Food Analytical Methods, 2013, vol. 6, no 4, p. 1170-1187.

url Repositori UJI: 


\title{
Application of fast gas chromatography-mass spectrometry in combination with the QuEChERS method for the determination of pesticide residues in fruits and vegetables
}

Laura Cherta, Joaquim Beltran, Francisco López, Félix Hernández

Research Institute for Pesticides and Water, University Jaume I, Castellón, Spain.

Food Analytical Methods (2013), 6 (4): 1170-1187

\begin{abstract}
A fast gas chromatography-mass spectrometry method has been developed for multiresidue determination of up to 56 pesticides in fruits and vegetables in a chromatographic run time of $<10 \mathrm{~min}$, using a single quadrupole mass spectrometer operating in selected ion monitoring mode. The well-known acetate-buffering version of the QuEChERS method has been used for sample preparation. Programmable temperature vaporizer injection of $3 \mu \mathrm{L}$ allowed reaching limits of detection between 0.15 and $15 \mu \mathrm{g} / \mathrm{kg}$ for most compounds in the sample matrices tested. The applicability of the method has been evaluated in apple, orange, carrot and tomato. Recoveries at three fortification levels (0.01, 0.1 and $0.5 \mathrm{mg} / \mathrm{kg}$ ) ranged from 70 to $120 \%$ for most compounds, with relative standard deviations below $20 \%$ in all cases. The developed method has been applied to fruit and vegetable samples from different Spanish provinces.
\end{abstract}

\section{Keywords}

Pesticides; Fast gas chromatography-mass spectrometry; Fruits and vegetables; Matrix effects; QuEChERS. 


\section{INTRODUCTION}

An extensive range of pesticides is widely used nowadays to protect crops from pests. Pesticide residues are strictly controlled by legislation in order to prevent water and food contamination and avoid unnecessary risks for animals and human beings. The European Commission (2005) has set harmonized maximum residue levels (MRLs) so as to regulate pesticides in food and assure food safety. Sensitive analytical techniques are required to verify MRLs accomplishment due to the low concentrations (e.g., at the micrograms per kilogram level) allowed by the legislation.

Many multiresidue gas chromatography-mass spectrometry (GC-MS) methods have been reported in the literature in different food commodities (Sandra et al. 2003; Mezcua et al. 2009), most of them using a single quadrupole mass spectrometer as analyzer. In the last years, tandem mass spectrometry (MS/MS) has emerged as a very interesting approach since it allows minimizing matrix interferences and chemical noise in the chromatograms, improving selectivity and sensitivity. Numerous applications based on GC-MS/MS have been reported for the determination of multiclass pesticides using triple quadrupole (Cervera et al. 2010; Frenich et al. 2005; Medina et al. 2009) or ion trap detector analyzers (González-Rodríguez et al. 2008; Zhang et al. 2008), some of them including around or more than 100 target analytes. In parallel to the interest of increasing the number of compounds in a single chromatographic run, there is a trend to decrease chromatographic run times in multiresidue analysis. At this point, the use of fast GC becomes an attractive approach since it allows an important reduction of analysis time (Dömötörová and Matisová 2008; Kirchner et al. 2005). The relevance of fast GC also comes from the attainment of better instrumental sensitivity, comparable in some cases to that reached with analyzers working under MS/MS mode. Thus, in a previous study (Cherta et al. 2012), low limits of quantification (LOQs) were achieved for pesticides and other organic pollutants in water matrices working with fast GC-MS using single quadrupole. A challenge would be to demonstrate the same capabilities for more complex matrices as fruits and vegetables. It is well known that limitations of single quadrupole are more evident when complex matrices are analyzed, especially due to the matrix effects (Hercegová et al. 2010). In this way, not only adequate chromatographic resolution is required but also an efficient separation of the analytes from the matrix components. An effective sample treatment is also necessary to facilitate the subsequent GC analysis. Nowadays, the trend is to head 
towards fast and simple approaches, as the Quick, Easy, Cheap, Effective, Rugged and Safe (QuEChERS) method, which was first developed by Anastassiades et al. (2003). Since then, it has been successfully implemented for a wide range of commodities in many routine laboratories and has been subjected to several changes to expand the method's capabilities and applications.

The original QuEChERS method was designed to allow the extraction of pesticide residues in fruits and vegetables with high percentage of water. It was based on solvent extraction carried out with acetonitrile $(\mathrm{MeCN})$ and subsequent cleanup based on dispersive solid-phase extraction (d-SPE) using a primary-secondary amine (PSA) sorbent and anhydrous $\mathrm{MgSO}_{4}$ to remove water. Later, two remarkable modifications of the original unbuffered method have been reported. These modifications have been adopted as the Association of Analytical Communities (AOAC) Official Method 2007.01 (Lehotay et al. 2005 a), which uses strong acetate buffering ( $\mathrm{pH}$ 4.8), and the European Committee for Standardization (CEN) Standard Method EN 15662 (Payá et al. 2007), which uses a weaker citrate buffering ( $\mathrm{pH}_{5}-5.5$ ). Both approaches pursue modifying buffering conditions, since the unbuffered original method had negative effects on some $\mathrm{pH}$-dependent pesticides. The AOAC method also includes the use of sorbents, such as $\mathrm{C}_{18}$ or graphitized carbon black (GCB) for fatty and pigmented foods, respectively, in order to improve the cleanup procedure. In the CEN version, disodium hydrogen citrate sesquihydrate and trisodium citrate dihydrate are also used in the extraction step (Payá et al. 2007; Camino-Sánchez et al. 2011). From the results published, it can be concluded that QuEChERS is a very flexible procedure that can be used as a template for adapting the method to analytes under study, matrix composition, analytical instruments, and analyst preferences (Lehotay et al. 2010). The use of $\mathrm{MeCN}$ as extraction solvent and its direct injection can be a drawback for splitless injection in GC due to its large expansion volume in the glass-liner, low volatility, or coextracted water presence. The use of programmable temperature vaporizer (PTV) injection becomes an interesting alternative that has received much attention when dealing with injection of $\mathrm{MeCN}$ extracts in GC. Another option is to make a solvent exchange into toluene (Zhou et al. 2011), ethyl acetate (Shi et al. 2010), or cyclohexane (Moreno et al. 2008), which also allows concentrating the final extract, compensating one of the disadvantages of QuEChERS, the absence of an extract preconcentration step. The use of other solvents, such as ethyl acetate or acetone as extractants, has been tested (Lehotay et al. 2010; Cunha et al. 2007), but MeCN still remains as the priority solvent for the 
QuEChERS procedure. The combination of $\mathrm{MeCN}$ as extractant combined with PTV injection has allowed reaching low limits of determination when combined with fast GC techniques (Hada et al. 2000; Hercegová et al. 2005; Korenková et al. 2003).

As it can be seen in the literature, only a limited number of studies have been reported about the combination of QuEChERS with fast GC for the determination of pesticide residues. Thus, Húšková et al. (2008) reported the determination of 61 pesticides in apple in a total chromatographic run time of $11 \mathrm{~min}$, demonstrating the possibilities of the single quadrupole as analyzer in fast GC. The separation of 18 pesticides in apple was achieved in 10 min working with single quadrupole, and the performance of analyte protectants compared with matrix-matched standards after the application of QuEChERS was studied (Kirchner et al. 2008). In that work, only apple was selected as the matrix under study. In another paper, 20 pesticides were determined in baby food using GC-MS with single quadrupole in $8 \mathrm{~min}$, testing the capabilities of the QuEChERS procedure versus other sample preparation methods (Hercegová et al. 2006). The possibility of working in negative chemical ionization mode was also tested for the determination of 25 pesticides in fruits and vegetables treated by QuEChERS with a chromatographic run time of only $11 \mathrm{~min}$ (Húšková et al. 2009). In general terms, several fast GC methods have been developed and validated for pesticides but, in most cases, for quite a limited number of compounds and sample matrices. Moreover, detailed studies of matrix effects when using single quadrupole are not frequent (Hajšlová and Zrostlíková 2003; Poole 2007).

In the present work, QuEChERS (based on the AOAC Official Method 2007.01) has been applied for the extraction of $5^{6}$ pesticides from 5 fruit and vegetable sample matrices. Subsequent determination has been made by fast GC-MS using single quadrupole as analyzer. The appropriate selection of target and reference ions for each analyte in each type of matrix has allowed the detection and quantification of most compounds (between 45 and 52 depending on the matrix and the concentration level) with satisfactory sensitivity. Single quadrupole provided sufficient fast data acquisition rates, so that an efficient determination of the analytes was achieved in short chromatographic time. Advantages of fast GC-MS and limitations of single quadrupole in the analysis of complex matrices have been also discussed, including the relevant aspect of confirmation of the analytes detected in samples. 


\section{EXPERIMENTAL}

\section{Reagents}

The pesticides investigated in this work are listed in Table 1. Reference standards were purchased from Dr. Ehrenstorfer (Augsburg, Germany). Stock standard solutions (around $500 \mu \mathrm{g} / \mathrm{mL}$ ) were prepared by dissolving reference standards in acetone and stored in a freezer at $-20^{\circ} \mathrm{C}$. Working standard mixtures for sample fortification and GC injection were prepared by dilution of stock solutions in acetonitrile.

Acetone, acetonitrile ( $\mathrm{MeCN}$ ), glacial acetic acid (HAc), anhydrous $\mathrm{MgSO}_{4}$ and anhydrous sodium acetate (NaAc) were purchased from Scharlab (Barcelona, Spain). All solvents were for pesticide residue analysis or were high-performance liquid chromatography grade. Two types of $2 \mathrm{~mL}$ microcentrifuge tubes for QuEChERS d-SPE containing $50 \mathrm{mg}$ PSA and $150 \mathrm{mg}$ anhydrous $\mathrm{MgSO}_{4}$ or $50 \mathrm{mg}$ PSA, $150 \mathrm{mg}$ anhydrous $\mathrm{MgSO}_{4}$ and $50 \mathrm{mg} \mathrm{C} \mathrm{C}_{18}$ were obtained from Teknokroma (Barcelona, Spain). 
Table 1. List of pesticides studied and experimental conditions of the optimized GC-MS method.

\begin{tabular}{|c|c|c|c|c|c|c|}
\hline \multirow[b]{2}{*}{$\begin{array}{c}\text { Peak } \\
\text { number }\end{array}$} & \multirow[b]{2}{*}{$\begin{array}{c}t_{R} \\
(\mathrm{~min})\end{array}$} & \multirow{2}{*}{$\begin{array}{l}\text { Window } \\
\text { (min) }\end{array}$} & \multirow[b]{2}{*}{ Compounds } & \multicolumn{3}{|c|}{ Monitored ions under SIM mode } \\
\hline & & & & $\begin{array}{c}\text { Target } \\
\text { ion }\end{array}$ & $\begin{array}{l}\text { Reference } \\
\text { ions }\end{array}$ & $\begin{array}{l}\text { Scan time } \\
\text { (s) }\end{array}$ \\
\hline 1 & 3.757 & $3.6-3.8$ & Dichlorvos (a) & 185 & 109,187 & 0.10 \\
\hline 2 & 4.567 & $3.8-4.63$ & Chlorpropham (a) & 213 & 127,154 & 0.10 \\
\hline 3 & 4.587 & & Trifluralin (b) & 264 & 290,306 & \\
\hline 4 & 4.704 & $4.63-4.85$ & Phorate (a) & 260 & 121,231 & 0.13 \\
\hline 5 & 4.777 & & alpha-HCH ${ }^{(b)}$ & 219 & 181,217 & \\
\hline 6 & 4.817 & & Atrazine (a) & 200 & 202,215 & \\
\hline 7 & 4.832 & & Hexachlorobenzene-13 $\mathrm{C}_{6}{ }^{*}$ & 292 & & \\
\hline 8 & 4.832 & & Hexachlorobenzene ${ }^{(\mathrm{c})}$ & 284 & 282,286 & \\
\hline 9 & 4.886 & $4.85-5.05$ & terbuthylazine- $\mathrm{D}_{5}{ }^{*}$ & 219 & & 0.13 \\
\hline 10 & 4.897 & & Terbuthylazine (a) & 214 & 173,229 & \\
\hline 11 & 4.905 & & beta-HCH (b) & 217 & 181,219 & \\
\hline 12 & 4.920 & & Propyzamide (a),(d) & 175 & 173,255 & \\
\hline 13 & 4.929 & & $\operatorname{Diazinon}^{(a),(d)}$ & 152 & 137,179 & \\
\hline 14 & 4.948 & & Lindane $^{(\mathrm{b}),(\mathrm{d})}$ & 181 & 183,219 & \\
\hline 15 & 5.091 & $5.05-5.25$ & Pirimicarb (a) & 166 & 138,238 & 0.10 \\
\hline 16 & 5.100 & & Chlorothalonil (c) & 266 & 264,268 & \\
\hline 17 & 5.215 & & Metribuzin (a) & 198 & 144,199 & \\
\hline 18 & 5.274 & $5.25-5.52$ & Chlorpyriphos methyl (a) & 286 & 197,288 & 0.20 \\
\hline 19 & 5.274 & & Parathion methyl (a) & 263 & 216,246 & \\
\hline 20 & 5.312 & & Alachlor (a) & 160 & 132,188 & \\
\hline 21 & 5.393 & & Heptachlor $^{(b)}$ & 272 & 100,102 & \\
\hline 22 & 5.413 & & Pirimiphos methyl (a) & 290 & 125,244 & \\
\hline 23 & 5.438 & & Fenitrothion (a) & 277 & 109,260 & \\
\hline 24 & 5.467 & & Malathion (a) & 173 & 125,127 & \\
\hline 25 & 5.567 & $5.52-5.72$ & Fenthion (a) & 245 & 279,280 & 0.15 \\
\hline 26 & 5.572 & & Metholachlor (a) & 162 & 146,238 & \\
\hline 27 & 5.583 & & Chlorpyriphos (a) & 314 & 197,199 & \\
\hline 28 & 5.588 & & Parathion ethyl (a) & 291 & 139,155 & \\
\hline 29 & 5.645 & & Aldrin (b) & 263 & 101,261 & \\
\hline 30 & 5.784 & $5.72-5.99$ & Cyprodinil (c) & 224 & 210,225 & 0.18 \\
\hline 31 & 5.827 & & Pendimethalin (a) & 252 & 162,192 & \\
\hline 32 & 5.876 & & Chlofenvinphos (a) & 267 & 269,323 & \\
\hline 33 & 5.868 & & Isodrin $(\mathrm{b})$ & 193 & 195,263 & \\
\hline 34 & 5.922 & & Quinalphos (a),(d) & 146 & 156,157 & \\
\hline 35 & 5.953 & & Tolylfluanid (c) & 238 & 137,240 & \\
\hline
\end{tabular}


Table 1 (continued).

\begin{tabular}{|c|c|c|c|c|c|c|}
\hline \multirow[b]{2}{*}{$\begin{array}{c}\text { Peak } \\
\text { number }\end{array}$} & \multirow[b]{2}{*}{$\begin{array}{c}t_{R} \\
(\min )\end{array}$} & \multirow[b]{2}{*}{ Window } & \multirow[b]{2}{*}{ Compounds } & \multicolumn{3}{|c|}{ Monitored ions under SIM mode } \\
\hline & & & & $\begin{array}{l}\text { Target } \\
\text { ion }\end{array}$ & $\begin{array}{l}\text { Reference } \\
\text { ions }\end{array}$ & $\begin{array}{l}\text { Scan time } \\
\text { (s) }\end{array}$ \\
\hline 36 & 6.059 & $5.99-6.28$ & Methidathion (a),(d) & 145 & 93,125 & 0.10 \\
\hline 37 & 6.115 & & trans-Chlordane $^{(\mathrm{b})}$ & 375 & 371,373 & \\
\hline 38 & 6.230 & & Endosulfan I (b) & 170 & 239,241 & \\
\hline 39 & 6.337 & $6.28-6.55$ & $p, p^{\prime}-\mathrm{DDE}-\mathrm{D}_{8}{ }^{*}$ & 254 & & 0.10 \\
\hline 40 & 6.355 & & $p, p^{\prime}-\mathrm{DDE}^{(\mathrm{b})}$ & 246 & 248,318 & \\
\hline 41 & 6.419 & & Buprofezin (c),(d) & 105 & 104,172 & \\
\hline 42 & 6.453 & & Dieldrin (b) & 263 & 265,277 & \\
\hline 43 & 6.655 & $6.55-6.88$ & Endrin (b) & 263 & 261,345 & 0.15 \\
\hline 44 & 6.723 & & Endosulfan II (b) & 195 & 241,339 & \\
\hline 45 & 6.732 & & p,p'-DDD (b) & 165 & 176,199 & \\
\hline 46 & 6.738 & & Ethion (a),(d) & 125 & 153,384 & \\
\hline 47 & 6.757 & & Oxadixyl (c) & 132 & 120,146 & \\
\hline 48 & 6.974 & $6.88-7.2$ & Propiconazole I (c) & 173 & 175,259 & 0.10 \\
\hline 49 & 7.020 & & Propiconazole II (c) & 173 & 175,259 & \\
\hline 50 & 7.020 & & $p, p^{\prime}-\mathrm{DDT}^{(\mathrm{b}),(\mathrm{d})}$ & 165 & 199, 212 & \\
\hline 51 & 7.032 & & Endosulfan sulfate ${ }^{(b)}$ & 272 & 227,274 & \\
\hline 52 & 7.306 & $7.2-7.42$ & Bifenthrin (a) & 181 & 165,166 & 0.10 \\
\hline 53 & 7.333 & & Phosmet (a),(d) & 160 & 104,161 & \\
\hline 54 & 7.356 & & Methoxychlor (b),(d) & 227 & 212,228 & \\
\hline 55 & 7.498 & $7.42-7.65$ & Tetradifon (c),(d) & 159 & 227,229 & 0.10 \\
\hline 56 & 7.548 & & Pyriproxyfen (c) & 136 & 137,186 & \\
\hline 57 & 7.730 & $7.65-7.85$ & Fenarimol (c),(d) & 139 & 219,251 & 0.10 \\
\hline 58 & 8.244 & $7.85-8.9$ & Cypermethrin (a),(d) & 163 & 127,181 & 0.10 \\
\hline 59 & 8.554 & & Fenvalerate ${ }^{(a),(d)}$ & 125 & 167,169 & \\
\hline
\end{tabular}

* ILIS used in this work.

(a), (b), (c) indicates the internal standard used for quantitative purposes: (a) terbutylazine- $\mathrm{D}_{5}$, (b) $p, p^{\prime}-\mathrm{DDE}-\mathrm{D}_{8}$, (c) hexachlorobenzene- ${ }^{13} \mathrm{C}_{6}$.

(d) Target ion modified in some matrices: propyzamide, 173 in carrot and tomato; diazinon, 179 in tomato; lindane, 219 in carrot and tomato; quinalphos, 156 in carrot; methidathion, 93 in tomato; buprofezin, 104 in orange and carrot and 172 in tomato; ethion, 384 in carrot and 153 in tomato; p,p'-DDT, 199 in apple, orange and tomato; phosmet, 104 in carrot; methoxychlor, 228 in orange; tetradifon, 227 in carrot; fenarimol, 219 in carrot; cypermethrin, 181 in carrot and tomato; fenvalerate, 169 in carrot. 



terbuthylazine- $\mathrm{D}_{5}$ (Dr. Ehrenstorfer, Augsburg, Germany) and hexachlorobenzene (HCB)${ }^{13} \mathrm{C}_{6}$ (Cambridge Isotope Labs Inc., Andover, MA, USA). A working ILIS mixed solution (of around $1000 \mathrm{ng} / \mathrm{mL}$ ) was prepared by dilution of individual stock solutions with $\mathrm{MeCN}$ and stored at $4{ }^{\circ} \mathrm{C}$.

\section{Sample material}

Five types of commodities, selected following the European Control Guidelines SANCO/3131/2007, 31 October 2007, were used in the validation study: orange was selected as a food with high acidity, apple and tomato as high water content commodity, carrot as high protein content commodity and olive as a representative matrix with a high fat content. Blank samples, used to perform the matrix-matched calibration and the validation study, were obtained from organic cultivars (pesticide-free).

Four different varieties from each food commodity were analyzed so as to test the applicability of the method and to investigate the presence of pesticides. Orange varieties were purchased from local markets in the Castellón province: Clementine (a variety of the mandarin orange), from Benicarló and Vila-real; Navelina, from Vila-real; and Navelate, from Almassora. All the four apple varieties, Royal Gala, Golden, Granny, and Fuji, were obtained from local markets in Castellón and Vila-real. Raff tomato variety was from Murcia (Spain); Kumato and Pear Cherry Tomato were purchased from local markets in Castellón; and hanging tomato was from Almería (Spain). Commercial carrots and Baby carrots were also purchased from local markets in Castellón, and the variety Mantesa and Mokum came from the Northern and Southern Spain, respectively.

\section{GC instrumentation}

Determinations were performed on a GC system (Shimadzu QP2010 Plus) equipped with an autosampler (Shimadzu AOC-500o) and coupled to a single quadrupole mass spectrometer (GCMS-QP2010 Plus). Compounds were separated on a SAPIENS-5MS capillary column (length $20 \mathrm{~m} \times$ I.D. $0.10 \mathrm{~mm} \times$ film thickness $0.10 \mu \mathrm{m}$ ) from Teknokroma. Injection $(3 \mu \mathrm{L})$ was performed in PTV mode, programmed as follows: $40{ }^{\circ} \mathrm{C}$ (hold time, $0.5 \mathrm{~min}$ ), maintaining the split valve open; once the valve is closed, heating at a rate of $400{ }^{\circ} \mathrm{C} / \mathrm{min}$ to $320^{\circ} \mathrm{C}$ (hold time, $0.5 \mathrm{~min}$ ), resulting in a total injection time of $1.70 \mathrm{~min}$.

8 
Initial oven temperature was maintained at $60^{\circ} \mathrm{C}$ for $1.70 \mathrm{~min}$ and then heated at a rate of $90{ }^{\circ} \mathrm{C} / \mathrm{min}$ to $225{ }^{\circ} \mathrm{C}$, then $15{ }^{\circ} \mathrm{C} / \mathrm{min}$ to $270{ }^{\circ} \mathrm{C}$ and finally $150^{\circ} \mathrm{C} / \mathrm{min}$ to $330{ }^{\circ} \mathrm{C}$ (2 $\mathrm{min}$ ), resulting in a total analysis time of $8.93 \mathrm{~min}$. Helium was used as carrier gas at a constant flow of $0.77 \mathrm{~mL} / \mathrm{min}$ (corresponding to a linear velocity of $39.1 \mathrm{~cm} / \mathrm{s}$ ).

MS was operated in the electron ionization mode $(70 \mathrm{eV})$. The source and the interface (transfer line) temperatures were adjusted to 225 and $300{ }^{\circ} \mathrm{C}$, respectively. The scan time in scan mode was set at $0.1 \mathrm{~s}$; when selected ion monitoring (SIM) mode was applied, scan time ranged from 0.1 to $0.2 \mathrm{~s}$. A solvent delay of $3.3 \mathrm{~min}$ was used to prevent damage to the filament of the ion source. Shimadzu software GCMSsolution was used to automatically process the data.

\section{Analytical procedure}

Fruit and vegetable samples were firstly homogenized in a food chopper. Then, $15 \mathrm{~g}$ of sample was weighted in a 50-mL polypropylene centrifuge tube and $375 \mu \mathrm{L}$ of surrogate solution mixture in MeCN (containing the three ILIS) was added and mixed on a vortex for 1 min. Extraction was carried out using $15 \mathrm{~mL} \mathrm{MeCN}$ (with $1 \% \mathrm{HAc}$ ), shaking by hand for $30 \mathrm{~s}$. Then, $6 \mathrm{~g}$ anhydrous $\mathrm{MgSO}_{4}$ and $1.5 \mathrm{~g}$ anhydrous NaAc were added and immediately shaken vigorously by hand to prevent formation of $\mathrm{MgSO}_{4}$ agglomerates. Then, the tube was centrifuged at $3000 \mathrm{rpm}$ for $2 \mathrm{~min}$.

For the cleanup step, $1 \mathrm{~mL}$ of the upper MeCN extract was poured into a d-SPE tube containing $150 \mathrm{mg} \mathrm{MgSO}_{4}$ and $50 \mathrm{mg}$ PSA (or $150 \mathrm{mg} \mathrm{MgSO}_{4}, 50 \mathrm{mg}$ PSA and $50 \mathrm{mg}$ $\mathrm{C}_{18}$ when oranges and olives were extracted). The tubes were shaken on a vortex for $30 \mathrm{~s}$ and centrifuged at 3000 rpm for $2 \mathrm{~min}$. The final $\mathrm{MeCN}$ extract was injected into the GC system under the experimental conditions indicated before. 
Matrix-matched standards for each sample matrix were prepared as follows: $500 \mu \mathrm{L}$ of the MeCN extract obtained from a blank sample were mixed with $50 \mu \mathrm{L}$ of the pesticide standard solution in $\mathrm{MeCN}$ at different concentrations, also containing the three ILIS. Each compound was quantified by using relative responses to the corresponding internal standard, as shown in Table 1.

\section{Validation study}

Validation study was carried out for apple, orange, carrot, tomato and olive samples in terms of linearity, accuracy, precision, LOQ and limit of detection (LOD). Blank samples were used to prepare spiked samples as follows: $15 \mathrm{~g}$ of sample was mixed with $150 \mu \mathrm{L}$ of the pesticide standard solution in $\mathrm{MeCN}$ at 1 or $5 \mu \mathrm{g} / \mathrm{mL}$ in order to obtain spiked samples at 0.01 or $0.05 \mathrm{mg} / \mathrm{kg}$, respectively; spiked samples at $0.1 \mathrm{mg} / \mathrm{kg}$ were obtained by mixing $15 \mathrm{~g}$ of sample with $1,500 \mu \mathrm{L}$ of the pesticide standard solution in $\mathrm{MeCN}$ at $5 \mu \mathrm{g} / \mathrm{mL}$. In all cases, $375 \mu \mathrm{L}$ of surrogate solution mixture in MeCN (containing the three ILIS) were also added and then left to stand over during an hour. Confirmation capability of the method for positive samples was also evaluated using ion intensity ratios. The effect of interfering peaks was also carefully studied.

Linearity was studied by injecting matrix-matched calibration standards $(n=3)$ in the range $1-500 \mathrm{ng} / \mathrm{mL}$ (corresponding to $0.001-0.5 \mathrm{mg} / \mathrm{kg}$ in sample). Linearity was considered satisfactory when the determination coefficient was higher than 0.99 and the residuals lower than $30 \%$ without any clear tendency.

Accuracy was estimated from recovery experiments at three concentration levels (0.01, 0.05 and $0.5 \mathrm{mg} / \mathrm{kg}$ ) ( $n=6$ each). Precision was expressed as repeatability in terms of relative standard deviation (RSD, in percent) $(n=6)$ at each fortification level.

LOQ was estimated as the analyte concentration that produced a peak signal ten times that of the background noise. It was calculated using the chromatograms at the lowest fortification level tested with satisfactory recovery $(70-120 \%)$ and precision (RSD $<20 \%$ ). LOD was estimated in the same way, but for a signal-to-noise ratio of 3 .

In order to confirm peak identity in the samples, the ratio between the quantification ion (target, $Q$ ) and the reference ions ( $q i$ ) was calculated for each compound in the samples and compared with the value obtained from matrix-matched standards. As a start 10 
point, maximum tolerances for $Q / q$ ratio deviation based on the European Commission Decision 2002/657/EC (European Commission Decision 2002) were considered, but modified in some cases. Agreement between retention time in the sample and the corresponding standard was also required to confirm a positive finding (maximum deviation $\pm 0.5 \%)$.

\section{RESULTS AND DISCUSSION}

\section{GC-MS optimization}

Optimization of the chromatographic conditions was first performed by injecting pesticide standard solutions in $\mathrm{MeCN}$ with the mass spectrometer operating in full scan mode. GC and MS parameters optimized in our previous paper (Cherta et al. 2012) were used, since several pesticides in common were determined in both cases. Injection mode was the only change to be considered on the chromatographic system, so optimization was focused on the PTV injection mode parameters.

Several injection temperatures were tested $\left(40-60^{\circ} \mathrm{C}\right)$, evaluating the sensitivity and chromatographic peak shape of early eluting compounds (more volatile). A temperature of $40{ }^{\circ} \mathrm{C}$ led to the best responses for these pesticides, so it was selected for further experiments. Initial column temperature was then studied between 50 and $80^{\circ} \mathrm{C} ; 60^{\circ} \mathrm{C}$ was chosen as the best value that provided better sensitivity and chromatographic peak shape. Final temperature was selected according to the chromatographic behavior of the last eluting compounds, which required temperatures between 300 and $350^{\circ} \mathrm{C} ; 330^{\circ} \mathrm{C}$ was selected, as it was high enough to elute these compounds with satisfactory sensitivity. All these experiments were performed by injecting $1 \mu \mathrm{L}$ of $100 \mathrm{ng} / \mathrm{mL}$ standard solution in MeCN using a glass liner packed with glass wool.

On the other hand, considering the PTV possibilities of injecting larger volumes, sensitivity was evaluated using injection volumes between 1 and $5 \mu \mathrm{L}$, paying special attention to solvent vent times. An injection volume of $3 \mu \mathrm{L}$, which required a solvent vent time of $0.5 \mathrm{~min}$, was considered as the most satisfactory. Once the $\mathrm{MeCN}$ was eliminated, the valve was closed and a heating rate of $400{ }^{\circ} \mathrm{C} / \mathrm{min}$ was applied until $320^{\circ} \mathrm{C}$ (hold time, 
$0.5 \mathrm{~min})$. The total injection time was $1.70 \mathrm{~min}$. During this time, column temperature was maintained at $60^{\circ} \mathrm{C}$.

MS parameters were optimized previously (Cherta et al. 2012); ion source and interface temperatures were maintained at 225 and $300{ }^{\circ} \mathrm{C}$, respectively, and scan time was set at $0.1 \mathrm{~s}$ in scan mode (scan speed of $3333 \mathrm{amu} / \mathrm{s}$ ), allowing the acquisition of 10 to 15 data points per peak.

In order to perform the simultaneous identification and quantification of the analytes, the three most abundant and/or characteristic ions for each compound were selected as target (typically the most abundant) and reference ions. Considering that a large number of compounds were determined in short chromatographic time, the unavoidable existence of some coelutions made necessary an accurate selection of $m / z$ values in order to use those ions that did not interfere in the quantitative determination of coeluting analytes. Table 1 shows the quantitative (target) and the reference (confirmative) ions selected for each compound.

The developed scan mode allowed the determination of 56 pesticides in run time as short as $8.93 \mathrm{~min}$, as can be seen in Fig. 1, which illustrates the total ion chromatogram for a standard mixture in $\mathrm{MeCN}$ at $200 \mathrm{ng} / \mathrm{mL}$. The lowest concentration level that could be detected under scan mode ranged from 10 to $70 \mathrm{ng} / \mathrm{mL}$, depending on the pesticide under study. In this way, an increase in sensitivity was required for an adequate quantification at low concentration levels, so a SIM method was created from the scan injection selecting the target and reference ions to be acquired. As the increase in the number of ions included in a SIM group also increases the scan time, resulting in the acquisition of less data points per peak, we established for our mass spectrometer a maximum of 20 ions in a SIM group (corresponding to a scan time of $0.2 \mathrm{~s}$ ) to obtain good peak shape and satisfactory quantification (Cherta et al. 2012; Maštovská and Lehotay 2003). 


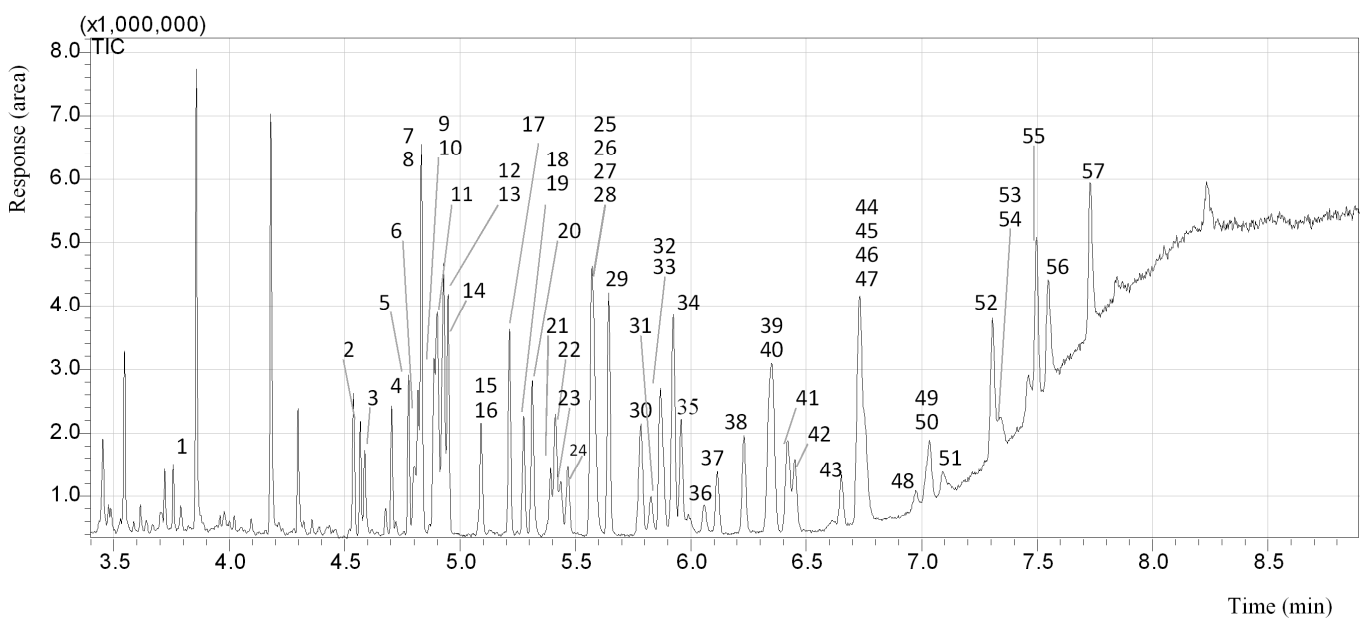

Fig. 1. GC-MS chromatogram of a mixed standard in acetonitrile (200 $\mathrm{ng} / \mathrm{mL})$ under the full scan method conditions (cypermethrin and fenvalerate could not be detected at $200 \mathrm{ng} / \mathrm{mL}$, so higher concentration levels were required for their determination under scan mode).

Finally, compounds were sorted into 16 SIM groups with 3 to 20 ions monitored in each one (from 1 to 7 compounds included in the different groups). Scan time varied between 0.1 and $0.2 \mathrm{~s}$, depending on the number of compounds included in each group (Table 1). Under these conditions, standard solutions down to $1-5 \mathrm{ng} / \mathrm{mL}$ could be easily analyzed and quantified. 


\section{QuEChERS procedure}

The extraction procedure applied in this work was based on the QuEChERS AOAC Official Method 2007.01, which uses acetate buffering (Lehotay et al. 2005 a, 2010; Koesukwiwat et al. 2011). It was applied without changes, but including the use of $\mathrm{C}_{18}$ in the cleanup step for oranges and olives. Application of this sample preparation method allows preparing around ten real samples in $<2 \mathrm{~h}$ (including matrix-matched calibration standards).

The QuEChERS method does not include solvent evaporation or concentration steps, leading to a ratio of approximately $1 \mathrm{~g}$ sample/mL in the final extract. As previously stated, the injection of $3 \mu \mathrm{L}$ allowed to notably increase sensitivity. Injection volumes above $3 \mu \mathrm{L}$ led to detector saturation under the selected conditions due to the introduction of larger amounts of sample matrix.

Although relatively clean extracts were obtained following this procedure, some interferences were observed in the chromatograms, depending on the type of matrix analyzed. Apple and orange samples presented less interferences than carrot and tomato. The olive matrix presented the worst chromatographic background, probably due to the presence of large lipid amounts that could not be completely removed even by adding $\mathrm{C}_{18}$ in the cleanup step. Moreover, we observed several interfering peaks, even at the characteristic analyte ions, making the quantification of analytes troublesome. On the other hand, fat usually forms an oily layer between the aqueous and MeCN phases, in which some pesticides could be retained, resulting in lower recoveries, as it has been reported in the literature (Lehotay et al. 2005 b). Improvement of the procedure should involve the use of other approaches reported to analyze olive matrices, such as the use of GCB as additional sorbent in the cleanup (Cunha et al. 2007; Lehotay et al. 2005 b; Gilbert-López et al. 2010 a, b), conventional SPE using Florisil as sorbent (Garrido Frenich et al. 2008), or direct sample introduction instead of PTV injection (Cunha et al. 2007), but they have not been tested in this work. 


\section{Study of matrix effects}

In order to evaluate matrix effects on MS responses, calibration curves prepared in pure solvent $(\mathrm{MeCN})$ and in matrix were compared. Considerable differences were observed in terms of calibration slopes, as illustrated in Fig. 2, using diazinon and trans-chlordane as representative examples. Higher values for the slope of fitted calibration curves were obtained for standards in solvent as a general tendency, even when using relative responses to ILIS. Thus, the use of matrix-matched calibration was necessary to correct for matrix effects and to achieve satisfactory quantitative applications. Additionally, due to the complexity of the sample, matrix components interfered with the analyte ions monitored. In a few cases, when the ion selected as target was heavily interfered in a specific matrix, the "cleanest" reference ion was then established as target ion in order to perform a correct quantification. Modifications related to the ions selected as target ions are indicated in Table 1 for each type of matrix. Reference ions were also interfered in some cases, making the confirmation of the analytes problematic. Fig. $\mathbf{3}$ shows three representative cases of spectral interferences: Fig. 3a illustrates the ideal situation, where none of the ions is interfered, so both quantification and identification/confirmation are adequate; in Fig. 3b, one of the reference ions is interfered, thus reducing identity confirmation capabilities; and Fig. 3c shows interferences observed for all the analyte ions, even for the target ion, making unfeasible the determination of tetradifon.
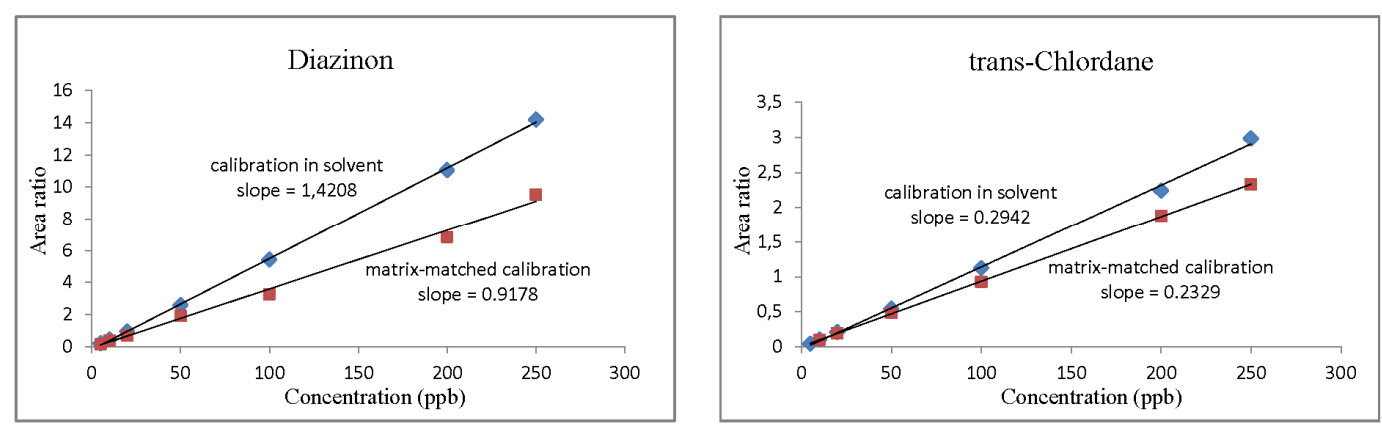

Fig. 2. Comparison of calibration curves obtained in solvent and in matrix for diazinon and transchlordane pesticides. 

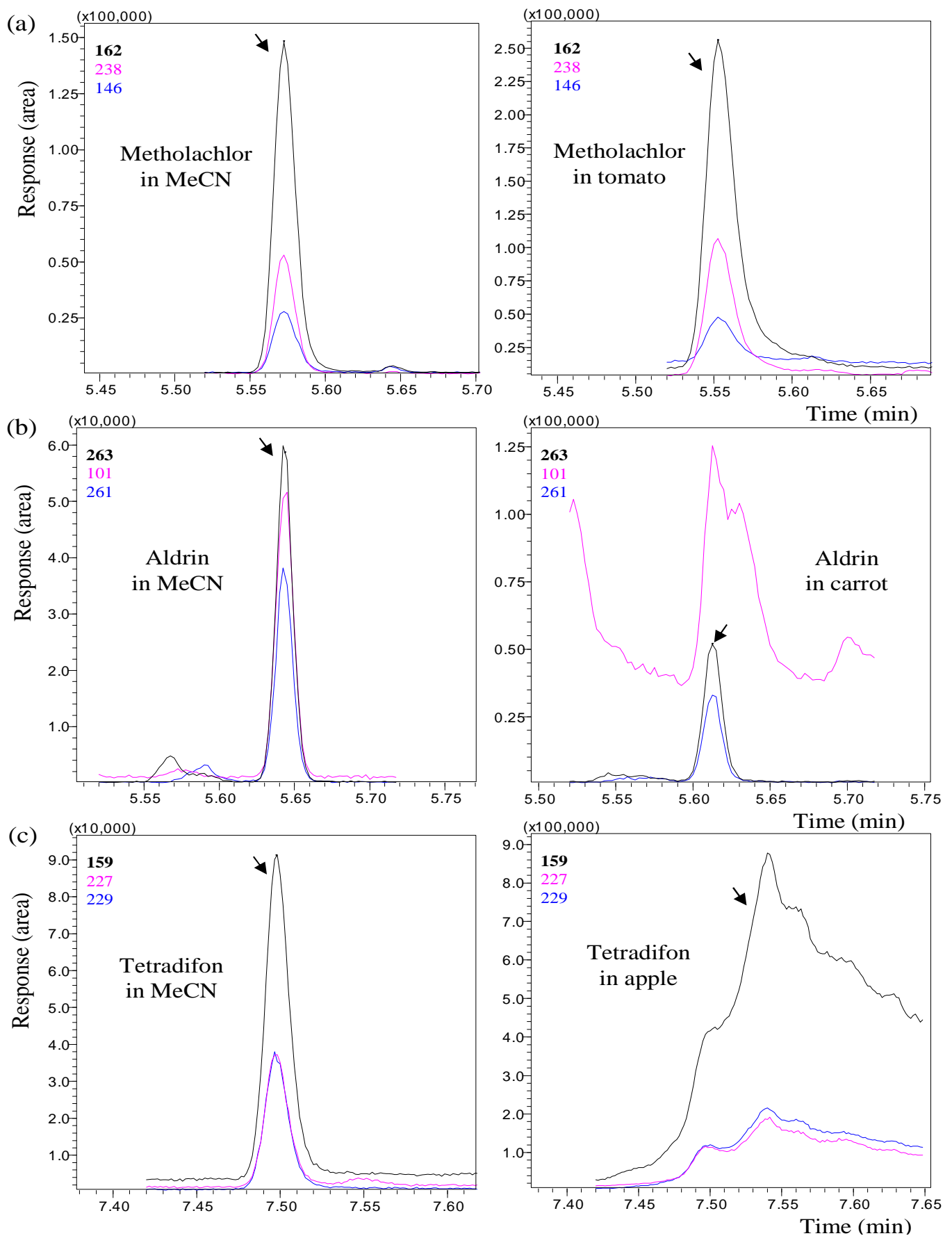

Fig. 3. Comparison of chromatographic responses for three selected pesticides in solvent at $50 \mathrm{ng} / \mathrm{mL}$ and in sample extracts spiked at $0.05 \mathrm{mg} / \mathrm{kg}$. Target ion (in bold) and two reference ions are shown. a) Metolachlor; b) aldrin; c) tetradifon. 
Therefore, a careful selection of the SIM ions has to be made due to coelutions between sample matrix components and analytes. The use of specific ions not interfered by coeluting components is necessary, although it was found difficult to be applied in some particular analyte/matrix combinations. Table 2 shows the target and reference ions interfered in each matrix.

Table 2. Interferences observed for target and reference ions in each type of matrix at the $0.01 \mathrm{mg} / \mathrm{kg}$ level.

\begin{tabular}{|c|c|c|c|c|c|c|c|c|c|c|c|c|c|c|c|}
\hline \multirow{2}{*}{ Compounds } & \multirow{2}{*}{$\mathrm{Q}$} & \multirow{2}{*}{$\mathrm{q}_{1}$} & \multirow{2}{*}{$\mathrm{q}_{2}$} & \multicolumn{3}{|c|}{ Apple } & \multicolumn{3}{|c|}{ Orange } & \multicolumn{3}{|c|}{ Carrot } & \multicolumn{3}{|c|}{ Tomato } \\
\hline & & & & $\mathrm{Q}$ & $\mathrm{q}_{1}$ & $\mathrm{q}_{2}$ & $\mathrm{Q}$ & $\mathrm{q}_{1}$ & $\mathrm{q}_{2}$ & $\mathrm{Q}$ & $\mathrm{q}_{1}$ & $\mathrm{q}_{2}$ & $\mathrm{Q}$ & $\mathrm{q}_{1}$ & $\mathrm{q}_{2}$ \\
\hline Lindane & 181 & 183 & 219 & & & $\mathrm{X}$ & & & $\mathrm{X}$ & $\mathrm{X}^{\mathrm{a}}$ & $\mathrm{X}$ & & $\mathrm{X}^{\mathrm{a}}$ & $\mathrm{X}$ & \\
\hline Pirimicarb & 166 & 138 & 238 & & & & & & & & & & & & \\
\hline Chlorothalonil & 266 & 264 & 268 & & & & & & & & & & & & \\
\hline Metribuzin & 198 & 144 & 199 & & & $\mathrm{X}$ & & & & & $\mathrm{X}$ & $\mathrm{X}$ & $X$ & $\mathrm{X}$ & $\mathrm{X}$ \\
\hline Chlorpyriphos methyl & 286 & 197 & 288 & & & & & & & & & & & $\mathrm{X}$ & \\
\hline Parathion methyl & 263 & 216 & 246 & & & & & & & & & & & & \\
\hline Alachlor & 160 & 132 & 188 & & & & & & & & & & & & \\
\hline Heptachlor & 272 & 100 & 102 & & & $\mathrm{X}$ & & $\mathrm{X}$ & $\mathrm{X}$ & & & $\mathrm{X}$ & & & $\mathrm{X}$ \\
\hline Pirimiphos methyl & 290 & 125 & 244 & & $\mathrm{X}$ & & & $\mathrm{X}$ & & & $\mathrm{X}$ & & & $\mathrm{X}$ & \\
\hline Fenitrothion & 277 & 109 & 260 & & $\mathrm{X}$ & & & $\mathrm{X}$ & & & $\mathrm{X}$ & & & $\mathrm{X}$ & \\
\hline Malathion & 173 & 125 & 127 & & & & & & & & $\mathrm{X}$ & & & $\mathrm{X}$ & \\
\hline Fenthion & 245 & 279 & 280 & & & & & & & & & & & & \\
\hline Metholachlor & 162 & 146 & 238 & & & & & & & & & & & & \\
\hline Chlorpyriphos & 314 & 197 & 199 & & & & & & & & & & & & \\
\hline Parathion ethyl & 291 & 139 & 155 & & $\mathrm{X}$ & $\mathrm{X}$ & & $\mathrm{X}$ & $\mathrm{X}$ & & $\mathrm{X}$ & $\mathrm{X}$ & $X$ & $\mathrm{X}$ & $\mathrm{X}$ \\
\hline Aldrin & 263 & 101 & 261 & & $\mathrm{X}$ & & & & & & $\mathrm{X}$ & & & & \\
\hline Cyprodinil & 224 & 210 & 225 & & & & & & & & & & $\mathrm{X}$ & $\mathrm{X}$ & $\mathrm{X}$ \\
\hline Pendimethalin & 252 & 162 & 192 & & & & & $\mathrm{X}$ & & & $\mathrm{X}$ & & & $\mathrm{X}$ & $\mathrm{X}$ \\
\hline Chlofenvinphos & 267 & 269 & 323 & & & & & & & & & & & & \\
\hline Isodrin & 193 & 195 & 263 & & & & & & & & & & & & \\
\hline Quinalphos & 146 & 156 & 157 & & & & & & & $\mathrm{X}^{\mathrm{a}}$ & & $\mathrm{X}$ & & & \\
\hline Tolylfluanid & 238 & 137 & 240 & & $\mathrm{X}$ & & & $\mathrm{X}$ & & & $\mathrm{X}$ & & & $\mathrm{X}$ & \\
\hline Methidathion & 145 & 93 & 125 & & $\mathrm{X}$ & & & $\mathrm{X}$ & & & $\mathrm{X}$ & & $\mathrm{X}^{\mathrm{a}}$ & & $\mathrm{X}$ \\
\hline trans-Chlordane & 375 & 371 & 373 & & & & & & & & & & & & \\
\hline Endosulfan I & 170 & 239 & 241 & & & & & & & & & & & & \\
\hline$p, p^{\prime}-\mathrm{DDE}$ & 246 & 248 & 318 & & & & & & & & & & & & \\
\hline Buprofezin & 105 & 104 & 172 & & & & $\mathrm{X}^{\mathrm{a}}$ & & & $\mathrm{X}^{\mathrm{a}}$ & & & $\mathrm{X}^{\mathrm{a}}$ & & \\
\hline Dieldrin & 263 & 265 & 277 & & & & & & & & & & & & \\
\hline
\end{tabular}


Table 2 (continued).

\begin{tabular}{|c|c|c|c|c|c|c|c|c|c|c|c|c|c|c|c|}
\hline \multirow{2}{*}{ Compounds } & \multirow{2}{*}{$\mathrm{Q}$} & \multirow{2}{*}{$\mathrm{q}_{1}$} & \multirow{2}{*}{$\mathrm{q}_{2}$} & \multicolumn{3}{|c|}{ Apple } & \multicolumn{3}{|c|}{ Orange } & \multicolumn{3}{|c|}{ Carrot } & \multicolumn{3}{|c|}{ Tomato } \\
\hline & & & & $\mathrm{Q}$ & $\mathrm{q}_{1}$ & $\mathrm{q}_{2}$ & $\mathrm{Q}$ & $\mathrm{q}_{1}$ & $\mathrm{q}_{2}$ & $\mathrm{Q}$ & $\mathrm{q}_{1}$ & $\mathrm{q}_{2}$ & $\mathrm{Q}$ & $\mathrm{q}_{1}$ & $\mathrm{q}_{2}$ \\
\hline Endrin & 263 & 261 & 345 & & & & & & & & & & & & \\
\hline Endosulfan II & 195 & 241 & 339 & & & & & & & & & & & & \\
\hline $\mathrm{p}, \mathrm{p}^{\prime}-\mathrm{DDD}$ & 165 & 176 & 199 & & & & & & & & & & & & \\
\hline Ethion & 125 & 153 & 384 & & & & & & & $\mathrm{X}^{\mathrm{a}}$ & $\mathrm{X}$ & & $\mathrm{X}^{\mathrm{a}}$ & & \\
\hline Oxadixyl & 132 & 120 & 146 & & & & & & & $\mathrm{X}$ & $\mathrm{X}$ & $\mathrm{X}$ & $\mathrm{X}$ & $\mathrm{X}$ & $\mathrm{X}$ \\
\hline Propiconazole I & 173 & 175 & 259 & & & & & & & & & & & & \\
\hline Propiconazole II & 173 & 175 & 259 & & & & & & & & & & & & \\
\hline$p, p^{\prime}$-DDT & 165 & 199 & 212 & $\mathrm{X}^{\mathrm{a}}$ & & & $\mathrm{X}^{\mathrm{a}}$ & & & & & & $\mathrm{X}^{\mathrm{a}}$ & & \\
\hline Endosulfan sulfate & 272 & 227 & 274 & & & & & $\mathrm{X}$ & & & & & & $\mathrm{X}$ & \\
\hline Bifenthrin & 181 & 165 & 166 & & & & & $\mathrm{X}$ & & & & & & & \\
\hline Phosmet & 160 & 104 & 161 & & & & $\mathrm{X}$ & $\mathrm{X}$ & $\mathrm{X}$ & $\mathrm{X}^{\mathrm{a}}$ & & $\mathrm{X}$ & & $\mathrm{X}$ & \\
\hline Methoxychlor & 227 & 212 & 228 & & & $\mathrm{X}$ & $\mathrm{X}^{\mathrm{a}}$ & $\mathrm{X}$ & & & & & & & \\
\hline Tetradifon & 159 & 227 & 229 & $\mathrm{X}$ & $\mathrm{X}$ & $\mathrm{X}$ & & $\mathrm{X}$ & & $\mathrm{X}^{\mathrm{a}}$ & & & & & \\
\hline Pyriproxyfen & 136 & 137 & 186 & $\mathrm{X}$ & $\mathrm{X}$ & $\mathrm{X}$ & & & & & & & & & \\
\hline Fenarimol & 139 & 219 & 251 & & & & & & & $\mathrm{X}^{\mathrm{a}}$ & & & & & \\
\hline Cypermethrin & 163 & 127 & 181 & & & & & & & $\mathrm{X}^{\mathrm{a}}$ & & & $\mathrm{X}^{\mathrm{a}}$ & & \\
\hline Fenvalerate & 125 & 167 & 169 & & & & & & & $\mathrm{X}^{\mathrm{a}}$ & $\mathrm{X}$ & & & $\mathrm{X}$ & \\
\hline
\end{tabular}

$\mathrm{X}$ matrix interference with the ion selected; Xa target ion is interfered and replaced for one reference ion in order to perform quantitative analysis.

Purple, blue and red colors indicate interferences in one, two and three ions, respectively.

Apple was the "cleanest" matrix since most of compounds were not affected by matrix interferences. Moreover, the quantitative ion $(Q)$ was not interfered, except for $p, p^{\prime}$-DDT, methoxychlor, tetradifon and pyriproxyfen, which prevented the validation of the method for these compounds. A similar trend was found for most pesticides in orange, although a higher number of ions, including the $Q$ ion in four cases, were interfered. Worse results were obtained in carrot and tomato matrices: half compounds presented interferences in at least one analyte ion; in some cases, all the three ions were interfered, so their validation could not be performed. The most common interferences occurred at low $m / z$ values, as 109 for fenitrothion, 102 for heptachlor and 125 for pirimiphos methyl, which were observed in all matrices. 


\section{Validation results}

The method developed was validated for apple, orange, carrot and tomato samples. Due to the higher complexity of olive samples, validation results were not satisfactory for most of the compounds. As indicated before, three ILIS were used as surrogates in order to correct for possible losses of analytes during the extraction process and/or instrumental deviations. Terbuthylazine- $\mathrm{D}_{5}$ was used as internal standard for herbicides, organophosphate insecticides, carbamates and pyrethroids; $p, p^{\prime}-\mathrm{DDE}^{-\mathrm{D}_{8}}$ was used for organochlorine pesticides and insecticides and trifluralin; and $\mathrm{HCB}^{-13} \mathrm{C}_{6}$ was used for fungicides and insecticides, such as buprofezin, pyriproxyfen and tetradifon. The internal standard used for each individual compound is shown in Table 1.

Linearity of responses using matrix-matched standards was studied in the range 0.001-0.5 mg/kg. Only those analytes for which sensitivity was higher, like dichlorvos, atrazine, chlorpyrifos methyl, chlorpyrifos, or bifenthrin, could be detected at the lowest calibration level tested, although the type of matrix also conditioned this value. Apple was the matrix that allowed extending the calibration range to the lowest concentration levels. Determination coefficients were better than 0.99 for all compounds and the residuals were lower than $30 \%$ in all matrices.

Accuracy and precision were evaluated by means of recovery experiments $(n=6)$ at three concentration levels (0.01, 0.05 and $0.1 \mathrm{mg} / \mathrm{kg}$ ) for each sample matrix. Results are shown in Tables 3, 4, 5 and 6. Apple matrix presented the best results in relation to recoveries and number of validated compounds. Four analytes ( $p, p^{\prime}$-DDT, methoxychlor, tetradifon and pyriproxyfen) were interfered by the matrix and could not be validated at any concentration level; methoxychlor showed poor sensitivity and could not be detected. The rest of the compounds presented recoveries between 70 and $120 \%$ in this matrix, with RSD lower than $20 \%$, and the wide majority were satisfactorily validated at the $0.01 \mathrm{mg} / \mathrm{kg}$ level. In orange, carrot and tomato samples, most analytes could be validated at the 0.05 and $0.5 \mathrm{mg} / \mathrm{kg}$ levels with satisfactory recoveries and precision. The number of compounds interfered by matrix components was higher in these matrices, as well as those compounds with poor sensitivity. Thus, chlorothalonil and tolylfluanid could not be validated in any of these matrices. It is known that these compounds are problematic in multiresidue analysis since they easily degrade during sample preparation, GC injection, and/or solution storage (Lehotay et al. 2005 c, 2007; Peruga 2012). No satisfactory results were also obtained for 
some pyrethroids, like cypermethrin and fenvalerate in carrot and tomato. Pyrethroids can also be problematic pesticides from an analytical point of view according to the literature (Lehotay et al. 2005 c).

LOQs between 2 and $20 \mu \mathrm{g} / \mathrm{kg}$ were obtained for most compounds in apple, orange, carrot, and tomato samples. A few values were around $30 \mu \mathrm{g} / \mathrm{kg}$ and higher LOQs $(100 \mu \mathrm{g} / \mathrm{kg})$ were obtained for some particular analyte/matrix combinations, as shown in

Tables 3, 4, 5 and 6. LODs were typically in the range $0.5^{-15} \mu \mathrm{g} / \mathrm{kg}$, which are of the same order to those reported in the recent literature (Nguyen et al. 2009; Steiniger et al. 2010; $\mathrm{Qu}$ et al.2010) and in agreement with regulations requirements (European Commission 2005).

Confirmation of peak identity in the samples was also conditioned by the presence of matrix interferences in some particular cases. A strict criterion based on the acquisition of one target $(Q)$ ion and two reference ions $(q i)$ and the accomplishment of $Q / q$ ratios in comparison with the reference standard values within acceptable deviations (European Commission Decision 2002) was firstly applied. The agreement in the retention time between sample and standard was also required. However, when matrix interferences coeluted with analytes, the $Q / q$ ratio could not be properly measured. But even without apparent interferences occurring, only in a very few cases the two $Q / q$ ratios were accomplished. This occurred especially at low analyte levels, where the low abundance of the ions can alter the expected $Q / q$ ratios. Thus, a more realistic criterion was applied for confirmation, consisting of agreement in retention time, three ions monitored observed in the sample, and at least one $Q / q$ ratio fulfilled (instead of the two available). 
Table 3. Average recovery (\%) and R.S.D. (\%, in parenthesis) obtained for apple samples ( $n=6)$ fortified at three concentration levels. Detection (LOD) and quantification (LOQ) limits.

\begin{tabular}{|c|c|c|c|c|c|}
\hline \multirow{2}{*}{ Compounds } & \multicolumn{3}{|c|}{ Fortification levels (mg/kg) } & \multirow{2}{*}{$\begin{array}{c}\mathrm{LOD} \\
(\mu \mathrm{g} / \mathrm{kg})\end{array}$} & \multirow{2}{*}{$\begin{array}{c}\mathrm{LOQ} \\
(\mu \mathrm{g} / \mathrm{kg})\end{array}$} \\
\hline & 0.01 & 0.05 & 0.5 & & \\
\hline Dichlorvos & $88(12)$ & $75(10)$ & $107(5)$ & 0.5 & 2 \\
\hline Chlorpropham & $105(3)$ & $104(6)$ & $97(9)$ & 0.8 & 3 \\
\hline Trifluralin & $99(7)$ & $80(9)$ & $96(8)$ & 0.6 & 2 \\
\hline Phorate & $104(9)$ & $99(7)$ & $102(7)$ & 0.6 & 2 \\
\hline alpha-HCH & $117(11)$ & $100(12)$ & $109(7)$ & 0.6 & 2 \\
\hline Atrazine & $99(4)$ & $90(6)$ & $103(5)$ & 0.6 & 2 \\
\hline Hexachlorobenzene & $99(1)$ & $108(2)$ & $95(2)$ & 0.5 & 2 \\
\hline Terbuthylazine & $97(2)$ & $88(12)$ & $103(5)$ & 0.5 & 2 \\
\hline beta-HCH & $111(5)$ & $89(4)$ & $99(6)$ & 4 & 14 \\
\hline Propyzamide & $110(5)$ & $100(6)$ & $86(5)$ & 4 & 14 \\
\hline Diazinon & $96(9)$ & $98(6)$ & $103(7)$ & 6 & 19 \\
\hline Lindane & $77(4)$ & $70(11)$ & $108(5)$ & 0.6 & 2 \\
\hline Pirimicarb & $82(10)$ & $96(9)$ & $103(5)$ & 0.5 & 2 \\
\hline Chlorothalonil & - & $\underline{40(10)}$ & $93(19)$ & 30 & 100 \\
\hline Metribuzin & $101(8)$ & $96(6)$ & $103(6)$ & 0.5 & 2 \\
\hline Chlorpyriphos methyl & $94(7)$ & $72(9)$ & $106(12)$ & 0.3 & 1 \\
\hline Parathion methyl & - & $72(7)$ & $107(13)$ & 5 & 15 \\
\hline Alachlor & $92(5)$ & $94(6)$ & $104(6)$ & 0.5 & 2 \\
\hline Heptachlor & $107(7)$ & $69(5)$ & $104(4)$ & 2 & 6 \\
\hline Pirimiphos methyl & $117(3)$ & $94(9)$ & $101(7)$ & 0.5 & 2 \\
\hline Fenitrothion & $113(4)$ & $78(8)$ & $82(13)$ & 2 & 6 \\
\hline Malathion & $105(7)$ & $66(5)$ & $95(17)$ & 2 & 6 \\
\hline Fenthion & - & $96(5)$ & $101(6)$ & 5 & 15 \\
\hline Metholachlor & $95(8)$ & $98(7)$ & $105(6)$ & 0.5 & 2 \\
\hline Chlorpyriphos & $118(1)$ & $106(9)$ & $106(7)$ & 0.5 & 2 \\
\hline Parathion ethyl & - & $86(7)$ & $98(6)$ & 5 & 15 \\
\hline Aldrin & $101(5)$ & $96(3)$ & $109(5)$ & 0.6 & 2 \\
\hline Cyprodinil & $92(8)$ & $99(8)$ & $87(7)$ & 0.5 & 2 \\
\hline Pendimethalin & - & $86(7)$ & $93(4)$ & 4 & 12 \\
\hline Chlofenvinphos & - & $73(3)$ & $98(7)$ & 5 & 15 \\
\hline Isodrin & $92(15)$ & $96(2)$ & $103(3)$ & 2 & 5 \\
\hline Quinalphos & $110(5)$ & $90(10)$ & $104(6)$ & 2 & 5 \\
\hline
\end{tabular}


Table 3 (continued).

\begin{tabular}{|c|c|c|c|c|c|}
\hline \multirow{2}{*}{ Compounds } & \multicolumn{3}{|c|}{ Fortification levels (mg/kg) } & \multirow{2}{*}{$\begin{array}{c}\mathrm{LOD} \\
(\mu \mathrm{g} / \mathrm{kg})\end{array}$} & \multirow{2}{*}{$\begin{array}{c}\text { LOQ } \\
(\mu \mathrm{g} / \mathrm{kg})\end{array}$} \\
\hline & 0.01 & 0.05 & 0.5 & & \\
\hline Tolylfluanid & - & - & $92(2)$ & 30 & 100 \\
\hline Methidathion & - & $74(4)$ & $100(12)$ & 4 & 12 \\
\hline trans-Chlordane & $114(3)$ & $93(4)$ & $103(4)$ & 2 & 6 \\
\hline Endosulfan I & - & $88(6)$ & $104(3)$ & 5 & 15 \\
\hline$p, p^{\prime}-\mathrm{DDE}$ & $103(4)$ & $99(3)$ & $102(4)$ & 0.6 & 2 \\
\hline Buprofezin & - & $102(6)$ & $90(3)$ & 5 & 15 \\
\hline Dieldrin & - & $92(4)$ & $110(4)$ & 7 & 21 \\
\hline Endrin & - & $100(6)$ & $107(6)$ & 7 & 21 \\
\hline Endosulfan II & - & - & $103(3)$ & 30 & 100 \\
\hline$p, p^{\prime}-\mathrm{DDD}$ & $88(9)$ & $73(11)$ & $101(5)$ & 2 & 6 \\
\hline Ethion & - & $109(8)$ & $102(6)$ & 8 & 25 \\
\hline Oxadixyl & - & $105(8)$ & $90(8)$ & 5 & 15 \\
\hline Propiconazole I & - & $104(7)$ & $89(6)$ & 12 & 38 \\
\hline Propiconazole II & - & $101(5)$ & $93(5)$ & 14 & 46 \\
\hline$p, p^{\prime}$-DDT & - & - & - & - & - \\
\hline Endosulfan sulfate & - & $\underline{40(23)}$ & $108(15)$ & 30 & 100 \\
\hline Bifenthrin & $95(6)$ & $99(16)$ & $102(6)$ & 0.6 & 2 \\
\hline Phosmet & $107(6)$ & $78(12)$ & $103(15)$ & 2 & 6 \\
\hline Methoxychlor & - & - & - & - & - \\
\hline Tetradifon & i. & i. & i. & - & - \\
\hline Pyriproxyfen & i. & i. & i. & - & - \\
\hline Fenarimol & $87(7)$ & $102(10)$ & $107(5)$ & 0.4 & 2 \\
\hline Cypermethrin & - & - & $106(7)$ & 30 & 100 \\
\hline Fenvalerate & - & $113(11)$ & $108(3)$ & 15 & 40 \\
\hline
\end{tabular}

Underlined, not acceptable results.

i., analyte not detected due to matrix interfences on the three analyte ions. 
Table 4. Average recovery (\%) and R.S.D. (\%, in parenthesis) obtained for orange samples (n=6) fortified at three concentration levels. Detection (LOD) and quantification (LOQ) limits.

\begin{tabular}{|c|c|c|c|c|c|}
\hline \multirow{2}{*}{ Compounds } & \multicolumn{3}{|c|}{ Fortification levels (mg/kg) } & \multirow{2}{*}{$\begin{array}{c}\mathrm{LOD} \\
(\mu \mathrm{g} / \mathrm{kg})\end{array}$} & \multirow{2}{*}{$\begin{array}{c}\mathrm{LOQ} \\
(\mu \mathrm{g} / \mathrm{kg})\end{array}$} \\
\hline & 0.01 & 0.05 & 0.5 & & \\
\hline Dichlorvos & $92(5)$ & $78(6)$ & $91(6)$ & 0.5 & 2 \\
\hline Chlorpropham & - & $102(8)$ & $97(7)$ & 5 & 15 \\
\hline Trifluralin & $69(9)$ & $107(7)$ & $105(7)$ & 1 & 4 \\
\hline Phorate & $114(5)$ & $89(6)$ & $98(5)$ & 2 & 6 \\
\hline alpha-HCH & $97(16)$ & $103(12)$ & $102(10)$ & 2 & 6 \\
\hline Atrazine & $100(11)$ & $87(6)$ & $101(4)$ & 2 & 6 \\
\hline Hexachlorobenzene & $76(5)$ & $110(4)$ & $97(4)$ & 0.6 & 2 \\
\hline Terbuthylazine & $95(3)$ & $92(10)$ & $98(9)$ & 0.6 & 2 \\
\hline beta-HCH & - & $94(9)$ & $104(7)$ & 8 & 25 \\
\hline Propyzamide & - & $98(5)$ & $103(7)$ & 6 & 20 \\
\hline Diazinon & - & $84(13)$ & $98(7)$ & 8 & 25 \\
\hline Lindane & $76(16)$ & $90(12)$ & $111(8)$ & 2 & 6 \\
\hline Pirimicarb & $107(13)$ & $91(4)$ & $99(9)$ & 1 & 3 \\
\hline Chlorothalonil & - & - & - & - & - \\
\hline Metribuzin & - & $91(11)$ & $92(8)$ & 5 & 15 \\
\hline Chlorpyriphos methyl & $101(4)$ & $81(6)$ & $90(14)$ & 0.6 & 2 \\
\hline Parathion methyl & - & $89(6)$ & $89(11)$ & 5 & 15 \\
\hline Alachlor & $107(7)$ & $86(8)$ & $92(10)$ & 2 & 6 \\
\hline Heptachlor & - & $91(16)$ & $82(10)$ & 4 & 12 \\
\hline Pirimiphos methyl & $110(7)$ & $78(6)$ & $87(15)$ & 2 & 6 \\
\hline Fenitrothion & - & - & $82(15)$ & 5 & 15 \\
\hline Malathion & - & - & $75(16)$ & 30 & 100 \\
\hline Fenthion & - & $96(11)$ & $90(14)$ & 7 & 21 \\
\hline Metholachlor & $118(5)$ & $78(4)$ & $99(10)$ & 1 & 3 \\
\hline Chlorpyriphos & - & $93(6)$ & $89(12)$ & 10 & 30 \\
\hline Parathion ethyl & - & $87(8)$ & $87(14)$ & 5 & 15 \\
\hline Aldrin & $106(9)$ & $90(10)$ & $92(8)$ & 0.6 & 2 \\
\hline Cyprodinil & $111(8)$ & $120(5)$ & $105(9)$ & 2 & 6 \\
\hline Pendimethalin & - & $85(12)$ & $79(15)$ & 8 & 25 \\
\hline Chlofenvinphos & - & $80(10)$ & $79(16)$ & 8 & 25 \\
\hline Isodrin & - & $97(15)$ & $94(11)$ & 4 & 12 \\
\hline Quinalphos & - & $79(6)$ & $100(10)$ & 6 & 18 \\
\hline
\end{tabular}


Table 4 (continued).

\begin{tabular}{|c|c|c|c|c|c|}
\hline \multirow{2}{*}{ Compounds } & \multicolumn{3}{|c|}{ Fortification levels (mg/kg) } & \multirow{2}{*}{$\begin{array}{c}\text { LOD } \\
(\mu \mathrm{g} / \mathrm{kg})\end{array}$} & \multirow{2}{*}{$\begin{array}{c}\mathrm{LOQ} \\
(\mu \mathrm{g} / \mathrm{kg})\end{array}$} \\
\hline & 0.01 & 0.05 & 0.5 & & \\
\hline Tolylfluanid & - & - & - & - & - \\
\hline Methidathion & - & - & $91(9)$ & 30 & 100 \\
\hline trans-Chlordane & - & $95(12)$ & $101(10)$ & 5 & 15 \\
\hline Endosulfan I & - & $100(3)$ & $105(8)$ & 6 & 20 \\
\hline$p, p^{\prime}-\mathrm{DDE}$ & $105(6)$ & $93(12)$ & $94(6)$ & 2 & 6 \\
\hline Buprofezin & - & $118(13)$ & $113(6)$ & 5 & 15 \\
\hline Dieldrin & - & - & $110(10)$ & 30 & 100 \\
\hline Endrin & - & - & $104(9)$ & 30 & 100 \\
\hline Endosulfan II & - & - & $112(9)$ & 30 & 100 \\
\hline$p, p^{\prime}-\mathrm{DDD}$ & - & $94(13)$ & $111(7)$ & 5 & 15 \\
\hline Ethion & - & $87(14)$ & $107(7)$ & 7 & 25 \\
\hline Oxadixyl & - & $114(8)$ & $109(14)$ & 9 & 30 \\
\hline Propiconazole I & - & $117(7)$ & $117(3)$ & 8 & 24 \\
\hline Propiconazole II & - & $115(7)$ & $116(6)$ & 12 & 38 \\
\hline$p, p^{\prime}-\mathrm{DDT}$ & - & - & - & - & - \\
\hline Endosulfan sulfate & - & - & - & - & - \\
\hline Bifenthrin & - & $82(17)$ & $96(8)$ & 5 & 15 \\
\hline Phosmet & i. & i. & i. & - & - \\
\hline Methoxychlor & - & - & - & - & - \\
\hline Tetradifon & - & $90(8)$ & $109(12)$ & 10 & 30 \\
\hline Pyriproxyfen & - & $118(10)$ & $116(13)$ & 5 & 15 \\
\hline Fenarimol & $110(5)$ & $97(11)$ & $101(8)$ & 1 & 4 \\
\hline Cypermethrin & - & - & $108(12)$ & 30 & 100 \\
\hline Fenvalerate & - & - & $102(5)$ & 30 & 100 \\
\hline
\end{tabular}

i., analyte not detected due to matrix interfences on the three analyte ions. 
Table 5. Average recovery (\%) and R.S.D. (\%, in parenthesis) obtained for carrot samples ( $n=6)$ fortified at three concentration levels. Detection (LOD) and quantification (LOQ) limits.

\begin{tabular}{|c|c|c|c|c|c|}
\hline \multirow{2}{*}{ Compounds } & \multicolumn{3}{|c|}{ Fortification levels (mg/kg) } & \multirow{2}{*}{$\begin{array}{c}\text { LOD } \\
(\mu \mathrm{g} / \mathrm{kg})\end{array}$} & \multirow{2}{*}{$\begin{array}{c}\text { LOQ } \\
(\mu \mathrm{g} / \mathrm{kg})\end{array}$} \\
\hline & 0.01 & 0.05 & 0.5 & & \\
\hline Dichlorvos & $96(9)$ & $97(5)$ & $87(4)$ & 0.6 & 2 \\
\hline Chlorpropham & - & $106(4)$ & $86(5)$ & 4 & 12 \\
\hline Trifluralin & $92(7)$ & $97(4)$ & $93(11)$ & 1 & 5 \\
\hline Phorate & $107(10)$ & $107(3)$ & $90(6)$ & 2 & 6 \\
\hline alpha-HCH & - & $110(13)$ & $94(6)$ & 5 & 15 \\
\hline Atrazine & - & $109(4)$ & $81(6)$ & 4 & 12 \\
\hline Hexachlorobenzene & $91(3)$ & $92(3)$ & $91(5)$ & 0.6 & 2 \\
\hline Terbuthylazine & $96(6)$ & $108(2)$ & $89(5)$ & 3 & 8 \\
\hline beta-HCH & - & $81(9)$ & $86(10)$ & 7 & 20 \\
\hline Propyzamide & $118(4)$ & $101(5)$ & $90(6)$ & 3 & 8 \\
\hline Diazinon & - & $95(2)$ & $85(7)$ & 6 & 18 \\
\hline Lindane & - & $80(9)$ & $94(9)$ & 5 & 15 \\
\hline Pirimicarb & $104(9)$ & $102(6)$ & $87(6)$ & 3 & 9 \\
\hline Chlorothalonil & - & $=$ & $200(8)$ & - & - \\
\hline Metribuzin & - & $113(5)$ & $105(12)$ & 7 & 20 \\
\hline Chlorpyriphos methyl & $82(8)$ & $98(12)$ & $85(8)$ & 1 & 5 \\
\hline Parathion methyl & - & - & $90(7)$ & 30 & 100 \\
\hline Alachlor & $103(18)$ & $109(8)$ & $89(6)$ & 2 & 5 \\
\hline Heptachlor & $92(11)$ & $100(6)$ & $91(8)$ & 2 & 5 \\
\hline Pirimiphos methyl & $86(12)$ & $107(3)$ & $89(8)$ & 0.6 & 2 \\
\hline Fenitrothion & - & $119(5)$ & $81(7)$ & 9 & 27 \\
\hline Malathion & - & $118(2)$ & $91(7)$ & 7 & 20 \\
\hline Fenthion & - & $112(4)$ & $85(5)$ & 8 & 24 \\
\hline Metholachlor & $117(9)$ & $101(6)$ & $90(6)$ & 1 & 5 \\
\hline Chlorpyriphos & - & $111(3)$ & $90(5)$ & 4 & 12 \\
\hline Parathion ethyl & - & $110(7)$ & $86(7)$ & 7 & 22 \\
\hline Aldrin & $93(9)$ & $87(3)$ & $95(7)$ & 2 & 6 \\
\hline Cyprodinil & - & $106(6)$ & n. a. & 5 & 15 \\
\hline Pendimethalin & - & $88(7)$ & $90(7)$ & 4 & 12 \\
\hline Chlofenvinphos & - & $108(6)$ & $81(5)$ & 6 & 18 \\
\hline Isodrin & - & $88(3)$ & $88(8)$ & 4 & 12 \\
\hline Quinalphos & - & $100(5)$ & $100(7)$ & 5 & 15 \\
\hline
\end{tabular}


Table 5 (continued).

\begin{tabular}{|c|c|c|c|c|c|}
\hline \multirow{2}{*}{ Compounds } & \multicolumn{3}{|c|}{ Fortification levels (mg/kg) } & \multirow{2}{*}{$\begin{array}{c}\mathrm{LOD} \\
(\mu \mathrm{g} / \mathrm{kg})\end{array}$} & \multirow{2}{*}{$\begin{array}{c}\text { LOQ } \\
(\mu \mathrm{g} / \mathrm{kg})\end{array}$} \\
\hline & 0.01 & 0.05 & 0.5 & & \\
\hline Tolylfluanid & - & - & - & - & - \\
\hline Methidathion & - & - & - & - & - \\
\hline trans-Chlordane & - & $98(4)$ & $91(7)$ & 6 & 18 \\
\hline Endosulfan I & - & $85(7)$ & $88(6)$ & 10 & 30 \\
\hline$p, p^{\prime}-\mathrm{DDE}$ & $96(9)$ & $99(1)$ & $90(7)$ & 2 & 6 \\
\hline Buprofezin & - & $74(13)$ & $96(7)$ & 7 & 21 \\
\hline Dieldrin & - & - & $94(6)$ & 30 & 100 \\
\hline Endrin & - & $98(7)$ & $91(7)$ & 7 & 25 \\
\hline Endosulfan II & - & - & $95(7)$ & 30 & 100 \\
\hline$p, p^{\prime}-\mathrm{DDD}$ & - & $109(4)$ & $68(7)$ & 7 & 25 \\
\hline Ethion & - & - & $95(7)$ & 30 & 100 \\
\hline Oxadixyl & i. & i. & i. & - & - \\
\hline Propiconazole I & - & $54(14)$ & $90(8)$ & 30 & 100 \\
\hline Propiconazole II & - & $93(14)$ & $95(10)$ & 15 & 45 \\
\hline$p, p^{\prime}-\mathrm{DDT}$ & - & - & $92(6)$ & 30 & 100 \\
\hline Endosulfan sulfate & - & $=$ & - & - & - \\
\hline Bifenthrin & $94(16)$ & $97(7)$ & $90(4)$ & 2 & 6 \\
\hline Phosmet & - & - & - & - & - \\
\hline Methoxychlor & - & - & $102(4)$ & 30 & 100 \\
\hline Tetradifon & - & - & - & - & - \\
\hline Pyriproxyfen & - & $112(3)$ & $96(10)$ & 4 & 12 \\
\hline Fenarimol & - & - & - & - & - \\
\hline Cypermethrin & - & - & - & - & - \\
\hline Fenvalerate & - & - & - & - & - \\
\hline
\end{tabular}

Underlined, not acceptable results.

i., analyte not detected due to matrix interfences on the three analyte ions. 
Table 6. Average recovery (\%) and R.S.D. (\%, in parenthesis) obtained for tomato samples ( $n=6)$ fortified at three concentration levels. Detection (LOD) and quantification (LOQ) limits.

\begin{tabular}{|c|c|c|c|c|c|}
\hline \multirow{2}{*}{ Compounds } & \multicolumn{3}{|c|}{ Fortification levels (mg/kg) } & \multirow{2}{*}{$\begin{array}{c}\mathrm{LOD} \\
(\mu \mathrm{g} / \mathrm{kg})\end{array}$} & \multirow{2}{*}{$\begin{array}{c}\mathrm{LOQ} \\
(\mu \mathrm{g} / \mathrm{kg})\end{array}$} \\
\hline & 0.01 & 0.05 & 0.5 & & \\
\hline Dichlorvos & $93(10)$ & $94(12)$ & $83(6)$ & 0.6 & 2 \\
\hline Chlorpropham & - & $91(6)$ & $91(6)$ & 6 & 20 \\
\hline Trifluralin & $113(11)$ & $109(9)$ & $113(9)$ & 0.6 & 2 \\
\hline Phorate & $97(6)$ & $113(7)$ & $95(6)$ & 0.6 & 2 \\
\hline alpha-HCH & $104(9)$ & $104(8)$ & $105(11)$ & 0.6 & 2 \\
\hline Atrazine & - & $108(10)$ & $91(12)$ & 5 & 15 \\
\hline Hexachlorobenzene & $100(4)$ & $120(1)$ & $98(2)$ & 0.3 & 1 \\
\hline Terbuthylazine & $93(9)$ & $111(10)$ & $100(8)$ & 2 & 6 \\
\hline beta-HCH & $110(10)$ & $91(12)$ & $86(11)$ & 2 & 6 \\
\hline Propyzamide & - & $69(29)$ & $107(8)$ & 30 & 100 \\
\hline Diazinon & $87(11)$ & $117(12)$ & $94(6)$ & 0.6 & 2 \\
\hline Lindane & $110(8)$ & $105(13)$ & $107(8)$ & 2 & 6 \\
\hline Pirimicarb & $98(14)$ & $89(9)$ & $96(6)$ & 2 & 5 \\
\hline Chlorothalonil & - & $=$ & - & - & - \\
\hline Metribuzin & i. & i. & i. & - & - \\
\hline Chlorpyriphos methyl & $93(11)$ & $99(14)$ & $102(11)$ & 0.6 & 2 \\
\hline Parathion methyl & - & - & $86(13)$ & 30 & 100 \\
\hline Alachlor & $109(6)$ & $117(8)$ & $102(7)$ & 2 & 5 \\
\hline Heptachlor & $105(8)$ & $97(6)$ & $103(13)$ & 1 & 3 \\
\hline Pirimiphos methyl & $98(5)$ & $107(10)$ & $99(10)$ & 0.6 & 2 \\
\hline Fenitrothion & - & - & $95(13)$ & 50 & 150 \\
\hline Malathion & - & $112(3)$ & $86(10)$ & 3 & 15 \\
\hline Fenthion & - & - & $95(13)$ & 30 & 100 \\
\hline Metholachlor & $97(7)$ & $93(14)$ & $101(7)$ & 0.6 & 2 \\
\hline Chlorpyriphos & $101(12)$ & $104(10)$ & $97(8)$ & 1 & 5 \\
\hline Parathion ethyl & i. & i. & i. & - & - \\
\hline Aldrin & $105(5)$ & $119(8)$ & $104(6)$ & 1 & 3 \\
\hline Cyprodinil & i. & i. & i. & - & - \\
\hline Pendimethalin & - & $96(11)$ & $104(9)$ & 5 & 15 \\
\hline Chlofenvinphos & - & $91(17)$ & $101(9)$ & 5 & 15 \\
\hline Isodrin & $111(7)$ & $110(10)$ & $105(7)$ & 2 & 6 \\
\hline Quinalphos & - & $105(16)$ & $109(10)$ & 5 & 15 \\
\hline
\end{tabular}


Table 6 (continued).

\begin{tabular}{|c|c|c|c|c|c|}
\hline \multirow{2}{*}{ Compounds } & \multicolumn{3}{|c|}{ Fortification levels (mg/kg) } & \multirow{2}{*}{$\begin{array}{c}\text { LOD } \\
(\mu \mathrm{g} / \mathrm{kg})\end{array}$} & \multirow{2}{*}{$\begin{array}{c}\text { LOQ } \\
(\mu \mathrm{g} / \mathrm{kg})\end{array}$} \\
\hline & 0.01 & 0.05 & 0.5 & & \\
\hline Tolylfluanid & - & - & - & - & - \\
\hline Methidathion & - & - & - & - & - \\
\hline trans-Chlordane & $116(6)$ & $106(7)$ & $105(8)$ & 0.6 & 2 \\
\hline Endosulfan I & - & $108(3)$ & $105(8)$ & 16 & 48 \\
\hline$p, p^{\prime}-\mathrm{DDE}$ & $100(5)$ & $113(6)$ & $103(7)$ & 1 & 3 \\
\hline Buprofezin & - & $118(7)$ & $99(4)$ & 5 & 15 \\
\hline Dieldrin & - & $106(5)$ & $110(5)$ & 5 & 15 \\
\hline Endrin & - & $115(2)$ & $110(8)$ & 7 & 22 \\
\hline Endosulfan II & - & - & $116(11)$ & 30 & 100 \\
\hline$p, p^{\prime}-\mathrm{DDD}$ & - & $89(5)$ & $85(12)$ & 10 & 32 \\
\hline Ethion & - & $125(7)$ & $101(15)$ & 30 & 100 \\
\hline Oxadixyl & i. & i. & i. & - & - \\
\hline Propiconazole I & - & - & $111(9)$ & 20 & 60 \\
\hline Propiconazole II & - & - & $106(4)$ & 20 & 60 \\
\hline$p, p^{\prime}-\mathrm{DDT}$ & - & - & - & - & - \\
\hline Endosulfan sulfate & - & $=$ & 97 (16) & 30 & 100 \\
\hline Bifenthrin & $102(11)$ & $113(13)$ & $97(7)$ & 1 & 3 \\
\hline Phosmet & - & - & - & - & - \\
\hline Methoxychlor & - & - & $81(22)$ & 30 & 100 \\
\hline Tetradifon & - & - & $90(11)$ & 40 & 115 \\
\hline Pyriproxyfen & $104(15)$ & $99(10)$ & $103(5)$ & 3 & 10 \\
\hline Fenarimol & - & - & $116(7)$ & 30 & 100 \\
\hline Cypermethrin & - & - & - & - & - \\
\hline Fenvalerate & - & - & - & - & - \\
\hline
\end{tabular}

Underlined, not acceptable results.

i., analyte not detected due to matrix interfences on the three analyte ions. 
As discussed before, several compounds presented heavy interferences in the reference ions, making the confirmation problematic in some cases. As can be seen in Table 2, most of matrix interferences affected only one reference ion (excluding of course the nonvalidated compounds that were interfered in the three ions selected), so the other one was available to be used for confirmation. Parathion ethyl, heptachlor, methoxychlor, lindane, metribuzin, quinalphos, ethion, phosmet, fenvalerate, pendimethalin, methidathion, propyzamide, pirimicarb and fenarimol showed interferences in both reference ions in some of the matrices. At higher pesticide concentrations (around or above $0.05 \mathrm{mg} / \mathrm{kg}$ ), the number of cases where the two reference ions were interfered was much lower and, although one reference ion was sometimes interfered, the other one commonly accomplished the ion ratio, making confirmation feasible. Thus, when the two reference ions were interfered, confirmation can be doubtful, and this occurred especially at the $0.01 \mathrm{mg} / \mathrm{kg}$ level. In these situations, a more selective analyzer as TOF MS or the use of tandem MS would be required for confirmation.

\section{Application to real samples}

The developed GC-MS procedure was applied to apple, orange, carrot and tomato samples, analyzing 4 different varieties of each matrix (in total, 16 samples analyzed). The insecticide chlorpyrifos was predominant in apple and orange samples. It was found in the apple Royal Gala and Golden varieties at 0.03 and $0.04 \mathrm{mg} / \mathrm{kg}$ (MRL, $0.5 \mathrm{mg} / \mathrm{kg}$ ), respectively, and in the Navelate $(0.05 \mathrm{mg} / \mathrm{kg})$ and Clementine $(0.17 \mathrm{mg} / \mathrm{kg})$ orange varieties (MRL, $0.3 \mathrm{mg} / \mathrm{kg}$ ). This insecticide is commonly applied in Spain for pest control in these crops. The herbicide terbuthylazine was also found in the Clementine orange variety, but at lower concentration (0.006 mg/kg; MRL, $0.1 \mathrm{mg} / \mathrm{kg}$ ). Bifenthrin was detected in the Navelina orange sample below the LOQ level (MRL, $0.1 \mathrm{mg} / \mathrm{kg}$ ) and also in the Royal Gala apple $(0.05 \mathrm{mg} / \mathrm{kg}$ ) and in the Fuji apple $(0.035 \mathrm{mg} / \mathrm{kg})$ varieties (MRL, $0.3 \mathrm{mg} / \mathrm{kg}$ ). The herbicides trifluralin and metolachlor and the fungicide HCB were found in the Raff tomato variety at levels around $0.002 \mathrm{mg} / \mathrm{kg}$ (MRL, 0.5, 0.05 and 0.01 , respectively). All the compounds detected were present at concentrations below the corresponding MRLs (for illustrative chromatograms of positive samples, see Fig. 4). 

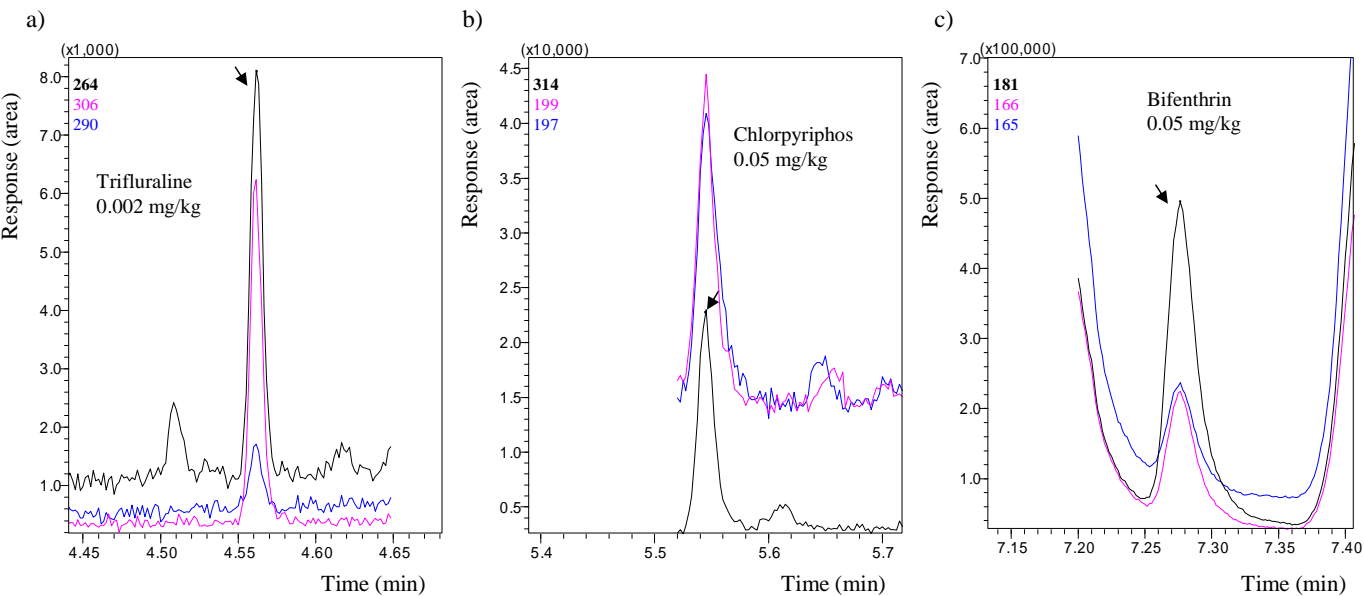

Fig. 4. Chromatograms for several compounds detected in a) Raff tomato, b) Navelina orange and c) Royal Gala apple.

Despite some problems found during validation in the accomplishment of ion ratios, this was not the case in the analysis of the 16 samples presented here, as none of the positive findings presented relevant matrix interferences, as shown in the examples of Fig. 4. So, the confirmation criterion based on the presence of three ions and the accomplishment of, at least, one ion ratio could be satisfactorily applied in all of them.

A nontarget analysis was also applied in these samples using the same GC-MS conditions under scan mode. Although sensitivity in scan mode does not allow reaching concentration levels as low as in the SIM mode, screening can be satisfactorily performed under this acquisition mode for compounds present at higher concentrations. None of the samples showed positive findings for nontarget pesticides, probably due to the low concentrations involved, but the potential of this technique for more concentrated compounds was demonstrated, with some positive findings for pyrene or major fruit components that, in any case, are not covered by the scope and aim of this work.

Additional analysis of the samples performed by GC-TOF MS using a method developed in our group (Cervera et al. 2012) allowed confirming all the positive findings reported by GC-MS, with the exception of trifluralin, HCB and metolachlor in the Raff tomato variety (concentrations around $0.002 \mathrm{mg} / \mathrm{kg}$ ) that could not be detected by GC-TOF due to its lower sensitivity. 


\section{CONCLUSIONS}

The potential of GC-MS using single quadrupole for multiresidue determination of pesticides in fruit and vegetable samples has been evaluated in this paper. A fast GC method has been developed for quantitative determination of 56 pesticides with a chromatographic run time of $<10 \mathrm{~min}$. Acquisition under SIM mode (three $\mathrm{m} / \mathrm{z}$ ions) provided satisfactory sensitivity although not enough selectivity for some analyte/matrix combinations, especially at the $0.01 \mathrm{mg} / \mathrm{kg}$ level. Quantification was satisfactory since acceptable results for accuracy and precision were obtained for most compounds in apple, orange, carrot, and tomato matrices at the three fortification levels (0.01, 0.1 and $0.5 \mathrm{mg} / \mathrm{kg}$ ). However, confirmation of positive findings was strongly conditioned by the presence of matrix-interfering peaks that coeluted with some reference ions. As a consequence, the accomplishment of two available $Q / q$ ratios was problematic, especially at low analyte levels. However, the confirmation criterion based on the measurement of three ions and the accomplishment of just one ion ratio was satisfactorily reached in the wide majority of analyte/matrix at all concentration levels tested.

QuEChERS sample treatment became an essential step in order to minimize as much as possible matrix coextractants in the matrices analyzed. An effective extraction was achieved and clean extracts were obtained for apple, orange, carrot and tomato samples, although the presence of interfering peaks could not be completely avoided for a few analytes. Despite using PSA and $\mathrm{C}_{18}$ for cleanup purposes in olive samples, their high fat content made this cleanup insufficient, impeding the accomplishment of satisfactory recoveries.

Analysis of samples allowed detecting, identifying and quantifying several pesticides like chlorpyrifos and bifenthrin in apple and orange, terbuthylazine in orange, and trifluralin, metolachlor and HCB in tomato. In all cases, the pesticide concentrations were below the MRLs set by the EU. Sample throughput was notably increased by applying the developed methodology, making the analysis of around 30 samples in 1 day with good sensitivity feasible. 


\section{Acknowledgments}

This work has been developed under the financial support of Bancaixa (P1-1B200925). The authors are very grateful to Izasa S.A. for providing the chromatographic system Shimadzu QP2010 Plus and acknowledge the financial support of Generalitat Valenciana, as research group of excellence PROMETEO/2009/054. The authors wish to thank Teknokroma for providing the 20-m GC column SAPIENS 5-MS. L. Cherta is very grateful to University Jaume I for his pre-doctoral grant.

\section{References}

Anastassiades M, Lehotay SJ, Štajnbaher D, Schenck FJ (2003) J AOAC Int 86:412

Camino-Sánchez FJ, Zafra-Gómez A, Ruiz-García J et al (2011) J Food Compos Anal 24:427

Cervera MI, Medina C, Portolés T et al (2010) Anal Bioanal Chem 397:2873

Cervera MI, Portolés T, Pitarch E, Beltrán J, Hernández F (2012) J Chromatogr A 1244:168

Cherta L, Beltran J, Portolés T, Hernández F (2012) Anal Bioanal Chem 402:2301

Cunha SC, Lehotay SJ, Mastovska K, Fernandes JO, Beatriz M, Oliveira PP (2007) J Sep Sci $30: 620$

Dömötörová M, Matisová E (2008) J Chromatogr A 1207:1

European Commission (2005) Regulation (EC) No. 396/2005

European Commission Decision 2002/657/EC. Official Journal of the European Community. 21 Aug 2002

Frenich AG, González-Rodríguez MJ, Arrebola FJ, Martínez Vidal JL (2005) Anal Chem $77: 4640$

Garrido Frenich A, Martínez Vidal JL, Pastor-Montoro E, Romero-González R (2008) Anal Bioanal Chem 390:947

Gilbert-López B, García-Reyes JF, Fernández-Alba AR, Molina-Díaz A (2010a) J Chromatogr A 1217:3736

Gilbert-López B, García-Reyes JF, Lozano A, Fernández-Alba AR, Molina-Díaz A (2010b) J Chromatogr A 1217:6022 
González-Rodríguez RM, Rial-Otero R, Cancho-Grande B, Simal-Gándara J (2008) J Chromatogr A 1196-1197:100

Hada M, Takino M, Yamagami T, Daishima S, Yamaguchi K (2000) J Chromatogr A 874:81 Hajšlová J, Zrostlíková J (2003) J Chromatogr A 1000:181

Hercegová A, Dömötörová M, Matisová E, Kirchner M, Otrekal R, Štefuca V (2005) J Chromatogr A 1084:46

Hercegová A, Dömötörová M, Kružlicová D, Matisová E (2006) J Sep Sci 29:1102

Hercegová A, Húšková R, Matisová E (2010) Int J Environ Anal Chem 90:188

Húšková R, Matisová E, Kirchner M (2008) Chromatographia 68(suppl 1):S49

Húšková R, Matisová E, Hrouzková S, Švorc L (2009) J Chromatogr A 1216:6326

Kirchner M, Matisová E, Hrouzková S, De Zeeuw J (2005) J Chromatogr A 1090:126

Kirchner M, Húšková R, Matisová E, Mocák J (2008) J Chromatogr A 1186:271

Koesukwiwat U, Lehotay SJ, Miao S, Leepipatpiboon N (2011) J Chromatogr A 1218:7039

Korenková E, Matisová E, Slobodník J (2003) J Sep Sci 26:1193

Lehotay SJ, Maštovská K, Lightfield AR (2005a) J AOAC Int 88:615

Lehotay SJ, Maštovská K, Yun SJ (2005b) J AOAC Int 88:630

Lehotay SJ, De Kok A, Hiemstra M, Van Bodegraven P (2005c) J AOAC Int 88:595

Lehotay SJ, O'Neil M, Tully J et al (2007) J AOAC Int 90:485

Lehotay SJ, Son KA, Kwon H et al (2010) J Chromatogr A 1217:2548

Maštovská K, Lehotay SJ (2003) J Chromatogr A 1000:153

Medina CM, Pitarch E, Portolés T, López FJ, Hernández F (2009) J Sep Sci 32:2090

Mezcua M, Martínez-Uroz MA, Wylie PL, Fernández-Alba AR (2009) J AOAC Int 92:1790

Moreno JLF, Frenich AG, Bolaños PP, Vidal JLM (2008) J Mass Spectrom 43:1235

Nguyen TD, Yun MY, Lee GH (2009) J Agric Food Chem 57:10095

Payá P, Anastassiades M, MacK D et al (2007) Anal Bioanal Chem 389:1697

Peruga A, Barreda M, Beltrán J, Hernández F (2013) Food Addit Contam 30:298

Poole CF (2007) J Chromatogr A 1158:241

Qu L, Zhang H, Zhu J, Yang G, Aboul-Enein HY (2010) Food Chem 122:327

Sandra P, Tienpont B, David F (2003) J Chromatogr A 1000:299 
Shi C, Gui W, Chen J, Zhu G (2010) Bull Environ Contam Toxicol 84:236

Steiniger D, Lu G, Butler J, Phillips E, Fintschenko Y (2010) J AOAC Int 93:1169

Zhang P, Hu X, Wang Y, Sun T (2008) 2nd International Conference on Bioinformatics and Biomedical Engineering (iCBBE), p 4113

Zhou L, Duan C, Wang M, Wang J, Zhang R (2011) J AOAC Int 94:313 